\title{
Effects of surface-active block copolymers with oxyethylene and fluoroalkyl side chains on the antifouling performance of silicone-based films
}

Elisa Martinelli ${ }^{\mathrm{a}}$, Deniz Gunes ${ }^{\mathrm{a}}$, Brandon M. Wenning ${ }^{\mathrm{b}}$, Christopher K. Ober ${ }^{\mathrm{b}}$, John A. Finlay $^{c}$, Maureen E. Callow ${ }^{c}$, James A. Callow ${ }^{c}$, Alessio Di Fino ${ }^{\mathrm{d}}$, Anthony S. Clare ${ }^{\mathrm{d}}$, Giancarlo Galli ${ }^{\text {** }}$

*Corresponding author. Email: giancarlo.galli@unipi.it

${ }^{a}$ Dipartimento di Chimica e Chimica Industriale and UdR Pisa INSTM, Università di Pisa, 56124 Pisa, Italy; ${ }^{b}$ Department of Materials Science and Engineering, Cornell University, Ithaca, New York 14850; ' School of Biosciences, University of Birmingham, Birmingham B15 2TT, UK; ${ }^{d}$ School of Marine Science and Technology, Newcastle University, Newcastle upon Tyne NE1 7RU, UK

Text: 5945

References: 2432

Tables: 87

Figures: about 200 


\begin{abstract}
Block copolymers made from a poly(dimethyl siloxane) ( $\mathrm{Si}$ ) and a poly(meth)acrylate carrying oxyethylene (EG) or fluoroalkyl (AF) side chains were synthesized and incorporated as surface-active components into a silicone matrix to produce cross-linked films with different surface hydrophilicity/phobicity. Near-edge X-ray absorption fine structure (NEXAFS) studies showed that film surfaces containing Si-EG were largely populated by the siloxane, with the oxyethylene chains present only to a minor extent. In contrast, the fluorinated block proved to be selectively segregated to the polymer-air interface in films containing Si-AF. Such differences in surface composition were reflected in the biological performance of the coatings. While the films with Si-EG showed a higher removal of both Ulva linza sporelings and Balanus amphitrite juveniles than the silicone control, those with $\mathrm{Si}-\mathrm{AF}$ exhibited excellent antifouling properties, preventing the settlement of cyprids of B. amphitrite.
\end{abstract}

Keywords: antifouling coating; fouling-release coating; surface-active polymer; block copolymer; Ulva linza; Balanus amphitrite. 


\section{Introduction}

Biofouling poses risks to a wide variety of wetted surfaces from medical devices (Werner et al. 2007, Kania et al. 2010, Bianco et al. 2015) to membranes for water purification (Vrouwenvelder et al. 2009), as well as to entire industries, such as paper manufacturing, food processing, underwater construction, and desalination plants (Flemming et al. 2009). In particular, the fouling of ships' hulls results in increased operational and maintenance costs (Townsin 2003; Schultz et al. 2011). The control of fouling by biocidal antifouling paints imposes environmental burdens (Thomas and Brooks 2010), hence new technologies are required.

A wide range of non-toxic alternatives to biocidal antifouling coatings has been investigated in recent years involving, for example, the manipulation of surface topography (Long et al. 2010; Scardino et al. 2011) and self-polishing capability (Duong et al. 2015), and the incorporation of bioactive molecules that deter the settlement of the colonising stages (eg Fusetani and Clare 2006; McMaster et al. 2009; Qian et al. 2010) or degrade the adhesives responsible for bonding the cell/organism to the substratum (Olsen et al. 2007; Leroy et al. 2008; Aldred and Clare 2008; Clare and Aldred 2009; Tasso et al. 2009). However, the most successful technologies that control fouling without the use of biocides are fouling-release coatings based on silicone elastomers, which release accumulated foulants when exposed to suitable hydrodynamic shear forces generated by movement through the water (eg Kavanagh et al. 2005). The basis of low adhesion of fouling organisms to silicone coatings has been attributed to a number of factors including surface energy (Brady and Singer 2000), bulk modulus (Brady and Singer 2000; Kim et al. 2007, 2008) and thickness of the coating (Brady and Singer 2000; Wendt et al. 2006; Kim et al. 2007, 2008). Recent research on fouling-release coatings has focussed on improving the performance of silicone by, for example, the preparation of urethane-siloxanes (Sommer et al. 2010), incorporation of oils (Kavanagh et al., 2003), nanofillers (Beigbeder et al. 2008) and tethered antimicrobials (Majumdar et al. 2008).

Other strategies have been reported for the development of antifouling/foulingrelease coatings containing hydrophilic and hydrophobic components, eg the crosslinking of polyethylene glycol (PEG) with hyperbranched fluoropolymers (Gudipati et al. 
2004; Imbesi et al. 2012), UV photocross-linking of mixtures containing PEG and fluorinated macromonomers (Wang et al. 2011; Martinelli et al. 2015b), self-assembling of block copolymers (Martinelli et al. 2008; Tan et al. 2010), multilayers of fluorinated/PEGylated polyions (Zhu et al. 2014) and incorporation of surface-active polymers (Krishnan et al. 2006, Martinelli et al. 2011a). The chemical design of surfaceactive polymers has mainly dealt with introducing combined or mixed oxyethylene and fluoroalkyl segments into polystyrene-based polymers (Weinman et al. 2009; Park et al. 2010) or into polysiloxane-based polymers (Martinelli et al. 2012a; Martinelli et al. 2015a). There are very few examples in literature of coatings containing fluorine-free surface-active block copolymers with antifouling/fouling-release potential (Sundaram et al. 2011; Cho et al. 2011).

The aim of this work was to compare the antifouling/fouling-release activity of a non-fluorinated coating with that of a closely related fluorinated one against two of the most invasive and common fouling macroorganisms, viz. Ulva linza and Balanus amphitrite (= Amphibalanus amphitrite), at the different colonising stages of their life cycles. Two diblock copolymers were prepared from the same polydimethylsiloxane first block but differed in the poly(meth)acrylate second block alternatively carrying a hydrophilic oxyethylene or a hydrophobic/lipophobic fluoroalkyl side chain. The copolymers were dispersed as surface-active components in a cross-linked silicone matrix. The film surfaces were characterized by dynamic contact angle and near-edge Xray fine absorption structure (NEXAFS) analyses to probe their chemical structure for correlation with the antifouling/fouling-release properties against $U$. linza and $B$. amphitrite.

The macroalga $U$. linza commonly fouls ships and other submerged structures. Motile zoospores released by the adult plants form the starting point of the assay. The swimming spores settle (attach) and become permanently adhered to the substrate through discharge of a glycoprotein adhesive (Callow and Callow 2006). The spores rapidly germinate and grow into sporelings (young plants), which adhere weakly to silicone fouling-release coatings (Chaudhury et al. 2005; Cassé et al. 2007). The barnacle, B. amphitrite (Clare and Høeg 2008; Evans 2009), is cosmopolitan in its distribution and an economically important fouling species. The adults liberate nauplii that develop 
through six planktonic stages to the highly specialised settlement stage, the cypris larva (Clare and Matsumura 2000). The cyprid explores surfaces using a reversible adhesion mechanism (Aldred and Clare 2008; Clare and Aldred 2009; Maruzzo et al. 2011) and once a suitable site for settlement has been located, permanent cement is discharged that anchors the larva in place during metamorphosis and early juvenile development (Phang et al. 2006; Aldred and Clare 2008; Clare and Aldred 2009). Adult cement is produced periodically as the barnacle grows (Walker 1981). Adults adhere weakly to silicone elastomers (Swain et al. 1992; Berglin and Gatenholm 1999; Kavanagh et al. 2005; Conlan et al. 2008).

\section{Materials}

Tetrahydrofuran (THF), anisole and triethylamine $\left(\mathrm{NEt}_{3}\right)$ were distilled under nitrogen prior to use. Monocarbinol-terminated polydimethylsiloxane $\left(M_{\mathrm{n}}=1000 \mathrm{~g} \mathrm{~mol}^{-1}, \mathrm{Si}-\mathrm{OH}\right)$ (Gelest), bissilanol-terminated polydimethylsiloxane $\left(M_{\mathrm{n}}=26000 \mathrm{~g} \mathrm{~mol}^{-1}\right.$, PDMS $)$ (Gelest), polydiethoxysiloxane ( $M_{\mathrm{n}}=134 \mathrm{~g} \mathrm{~mol}^{-1}$, ES40) (Gelest), bismuth neodecanoate (BiND) (Aldrich), 1H,1H,2H,2H-perfluorooctyl acrylate (AF) (Fluorochem, 97\%), polyethyleneglycol methyl ether methacrylate $\left(M_{\mathrm{n}}=300 \mathrm{~g} \mathrm{~mol}^{-1}\right.$, EG) (Aldrich), 2bromo-isobutyryl bromide (BiBB) (Aldrich, 98\%), $\mathrm{CuBr}$ (Aldrich, 99.9\%) and 1,1,4,7,10,10-hexamethyltriethylenetetramine (HMTETA) (Aldrich, 97\%) were used without further purification.

\section{Synthesis of macroinitiator $\mathrm{Si-Br}$}

The macroinitiator was synthesized according to a previous procedure (Huan et al. 2001; Martinelli et al. 2011b): Si-OH (7.00 g, $7.00 \mathrm{mmol})$ was dissolved in THF $(85 \mathrm{~mL})$ with $\mathrm{NEt}_{3}(3.9 \mathrm{~mL}, 28 \mathrm{mmol})$ under nitrogen. BiBB $(1.3 \mathrm{~mL}, 7 \mathrm{mmol})$ in THF $(15 \mathrm{~mL})$ was then slowly added. The reaction was carried out at ambient temperature for $24 \mathrm{~h}$. The final suspension was filtered and the solvent was then removed under vacuum. The resulting yellow oil was taken up in dichloromethane and washed with $2.5 \% \mathrm{NaHCO}_{3}$, $2.5 \% \mathrm{HCl}$, and distilled water. The organic layer was isolated and dried over $\mathrm{Na}_{2} \mathrm{SO}_{4}$ and the volatiles were removed under vacuum to yield $\mathrm{Si}-\mathrm{Br}$ as a pale yellow oil ( $88 \%$ yield). 
${ }^{1} \mathrm{H}$ NMR $\left(\mathrm{CDCl}_{3}\right): \delta(\mathrm{ppm})=0.1\left(\mathrm{SiCH}_{3}\right), 0.6\left(\mathrm{SiCH}_{2}\right), 0.9\left(\mathrm{CH}_{2} \mathrm{CH}_{3}\right), 1.3$ $\left(\mathrm{CH}_{3} \mathrm{CH}_{2} \mathrm{CH}_{2} \mathrm{CH}_{2} \mathrm{Si}\right), 1.6\left(\mathrm{CH}_{3} \mathrm{CH}_{2}\right), 1.9\left(\mathrm{C}_{\left.\left(\mathrm{CH}_{3}\right)_{2}\right),} 3.4\left(\mathrm{COOCH}_{2} \mathrm{CH}_{2} \mathrm{OCH}_{2}\right), 3.7\right.$ $\left(\mathrm{SiCH}_{2} \mathrm{CH}_{2} \mathrm{OCH}_{2}\right), 4.4\left(\mathrm{COOCH}_{2}\right)$. FT-IR (film): $\bar{v}\left(\mathrm{~cm}^{-1}\right)=2961(v \mathrm{CH}$ aliphatic), 1740 $\left(v \mathrm{C}=\mathrm{O}\right.$ ester), $1260\left(v \mathrm{SiCH}_{3}\right), 1090-1022(v \mathrm{CO}, v \mathrm{SiO}), 800\left(v \mathrm{SiCH}_{3}\right)$

\section{Synthesis of block copolymer Si-AF}

Si-Br (1.20 g, $1.2 \mathrm{mmol}), \operatorname{AF}(3.51 \mathrm{~g}, 8.4 \mathrm{mmol})$, HMTETA $(276 \mathrm{mg}, 1.2 \mathrm{mmol})$ and anisole $(12 \mathrm{~mL})$ were introduced into a dry Schlenk flask. After three freeze-thaw pump cycles, $\mathrm{CuBr}(172 \mathrm{mg}, 1.2 \mathrm{mmol})$ was added under nitrogen and the solution was deoxygenated by four freeze-thaw pump cycles. The polymerization was let to proceed for $66 \mathrm{~h}$ at $115^{\circ} \mathrm{C}$. When the reaction was stopped the polymer mixture was dissolved in chloroform and washed with distilled water until the disappearance of the green/blue color. The solvent was removed under vacuum and the polymer was purified by repeated precipitations from chloroform solutions in methanol (50\% yield). The resulting block copolymer Si-AF had number average degrees of polymerization of the Si and AF blocks of 11 and 9 , respectively $\left(M_{\mathrm{n}, \mathrm{NMR}}=5000 \mathrm{~g} \mathrm{~mol}^{-1}, M_{\mathrm{n}, \mathrm{GPC}}=2700 \mathrm{~g} \mathrm{~mol}^{-1}, M_{\mathrm{w}} / M_{\mathrm{n}}=1.14\right)$.

${ }^{1} \mathrm{H}$ NMR $\left(\mathrm{CDCl}_{3}\right): \delta(\mathrm{ppm})=0.1\left(\mathrm{SiCH}_{3}\right), 0.5\left(\mathrm{SiCH}_{2}\right), 0.9-2.6\left(\mathrm{CH}_{3} \mathrm{CH}_{2} \mathrm{CH}_{2}\right.$, $\left.\mathrm{SiCH}_{2} \mathrm{CH}_{2}, \mathrm{C}\left(\mathrm{CH}_{3}\right)_{2}, \mathrm{CH}_{2} \mathrm{CF}_{2}, \mathrm{CHCH}_{2}\right)$, 3.4-3.6 $\left(\mathrm{COOCH}_{2} \mathrm{CH}_{2} \mathrm{OCH}_{2}\right)$, $4.4\left(\mathrm{COCH}_{2}\right.$, $\left.\mathrm{COOCH}_{2} \mathrm{CH}_{2} \mathrm{CF}_{2}\right) .{ }^{19} \mathrm{~F} \mathrm{NMR}\left(\mathrm{CDCl}_{3} / \mathrm{CF}_{3} \mathrm{COOH}\right): \delta(\mathrm{ppm})=-5\left(\mathrm{CF}_{3}\right),-38\left(\mathrm{CH}_{2} \mathrm{CF}_{2}\right)$, -46 to $-49\left(\mathrm{CF}_{2}\right),-51\left(\mathrm{CF}_{2} \mathrm{CF}_{3}\right)$. FT-IR (film): $\bar{v}\left(\mathrm{~cm}^{-1}\right)=2962(v \mathrm{CH}$ aliphatic $), 1740(v$ $\mathrm{C}=\mathrm{O}$ ester $), 1400-1000\left(v \mathrm{SiCH}_{3}, v \mathrm{CO}, v \mathrm{SiO}, v \mathrm{CF}\right), 803\left(v \mathrm{SiCH}_{3}\right), 652\left(\omega \mathrm{CF}_{2}\right)$.

\section{Synthesis of block copolymer Si-EG}

Si-Br (0.51 g, $0.5 \mathrm{mmol})$, EG (2.25 g, $7.5 \mathrm{mmol})$, HMTETA (115 mg, $0.50 \mathrm{mmol})$ and anisole $(9 \mathrm{~mL})$ were introduced into a dry Schlenk flask. After three freeze-thaw pump cycles, $\mathrm{CuBr}(71 \mathrm{mg}, 0.49 \mathrm{mmol})$ was added under nitrogen and the solution was deoxygenated by four freeze-thaw pump cycles. The polymerization was let to proceed for $66 \mathrm{~h}$ at $115^{\circ} \mathrm{C}$. When the reaction was stopped the polymer mixture was dissolved in anisole and washed with distilled water until the disappearance of the green/blue color. The solvent was removed under vacuum and the polymer was purified by repeated 
precipitations from chloroform solutions in n-hexane ( $45 \%$ yield). The resulting block copolymer Si-EG had number average degrees of polymerization of the Si and EG blocks of 11 and 37, respectively $\left(M_{\mathrm{n}, \mathrm{NMR}}=12300 \mathrm{~g} \mathrm{~mol}^{-1}, M_{\mathrm{n}, \mathrm{GPC}}=8500 \mathrm{~g} \mathrm{~mol}^{-1}, M_{\mathrm{w}} / M_{\mathrm{n}}=\right.$ 1.25).

${ }^{1} \mathrm{H}$ NMR $\left(\mathrm{CDCl}_{3}\right): \delta(\mathrm{ppm})=0.1\left(\mathrm{SiCH}_{3}\right), 0.5\left(\mathrm{SiCH}_{2}\right), 0.7-2.0\left(\mathrm{C}_{\mathrm{H}_{3}} \underline{\mathrm{C}}_{2} \mathrm{C}_{2}\right.$,

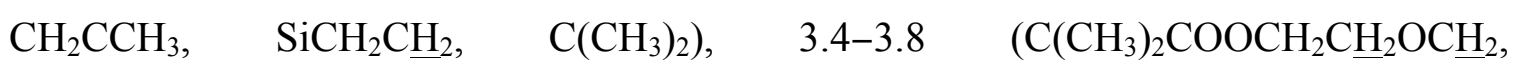
$\left(\mathrm{OCH}_{2} \mathrm{CH}_{2}\right)_{4} \mathrm{OCH}_{2}, 4.1\left(\mathrm{OCH}_{2} \mathrm{CH}_{2} \mathrm{OCO}, \mathrm{C}\left(\mathrm{CH}_{3}\right)_{2} \mathrm{COOC}_{2}\right)$. FT-IR (film): $\bar{v}\left(\mathrm{~cm}^{1}\right)=$ 2876 ( $v$ CH aliphatic), 1729 ( $v \mathrm{C}=\mathrm{O}$ ester), 1400-1000 (v $\left.\mathrm{SiCH}_{3}, v \mathrm{CO}, v \mathrm{SiO}\right), 803$ (v $\left.\mathrm{SiCH}_{3}\right)$.

The chemical composition of the copolymers was evaluated from the integrated areas of the ${ }^{1} \mathrm{H}$ NMR signals at $0.0 \mathrm{ppm}\left(\mathrm{Si}\left(\mathrm{CH}_{3}\right)_{2}\right.$ of $\left.\mathrm{Si}\right)$ and $3.4 \mathrm{ppm}\left(\mathrm{OCH}_{3}\right.$ of $\left.\mathrm{EG}\right)$ or $4.4 \mathrm{ppm}\left(\mathrm{COOCH}_{2}\right.$ of $\left.\mathrm{AF}\right)$. The attachment of the fluorinated block with the formation of a block copolymer was also demonstrated by ${ }^{19} \mathrm{~F}$ NMR spectroscopy investigations.

\section{Preparation of PDMS-based films}

The films were deposited in three steps onto previously washed (acetone) and dried glass slides $\left(76 \times 26 \mathrm{~mm}^{2}\right)$. In a typical preparation, the matrix PDMS $(5.0 \mathrm{~g})$, cross-linker ES40 $(0.125 \mathrm{~g})$ and catalyst BiND $(50 \mathrm{mg})$ were dissolved in ethyl acetate $(25 \mathrm{~mL})$. The solution was spray-coated using a Badger model 250 airbrush (50 psi air pressure). The films were dried at room temperature overnight and annealed at $120^{\circ} \mathrm{C}$ for $12 \mathrm{~h}$ to form the thin bottom layer (thickness $\sim 2 \mu \mathrm{m}$ ). A solution of the same amounts of PDMS, ES40 and BiND was cast on the bottom layer and cured at room temperature for a day and later at $120^{\circ} \mathrm{C}$ for $12 \mathrm{~h}$ to form the thicker middle layer (thickness $\sim 200 \mu \mathrm{m}$ ). Finally, the same solution, but containing the block copolymer, was spray-coated on top of the middle layer and cured at room temperature overnight and then at $120^{\circ} \mathrm{C}$ for $12 \mathrm{~h}$ (thickness $\sim 2 \mu \mathrm{m}$ ). The two copolymers Si-AF and Si-EG were dispersed at the same loadings of 4 and $8 \mathrm{wt} \%$ with respect to the PDMS matrix and the PDMS-based films derived therefrom are denoted as $\mathrm{Si}-\mathrm{AF}_{-} \mathrm{w}$ and $\mathrm{Si}_{-} \mathrm{EG}_{-} \mathrm{w}(\mathrm{w}=4$ and $8 \mathrm{wt} \%)$, respectively.

A blank PDMS coating (ie with no block copolymer) was also prepared as control. 


\section{Characterization}

${ }^{1} \mathrm{H}$ NMR and ${ }^{19} \mathrm{~F}$ NMR spectra were recorded with a Varian Gemini VRX300 spectrometer on $\mathrm{CDCl}_{3}$ and $\mathrm{CDCl}_{3} / \mathrm{CF}_{3} \mathrm{COOH}$ solutions, respectively.

Gel permeation chromatography (GPC) was carried out using a Jasco PU-1580 liquid chromatograph, having two PL gel $5 \mu \mathrm{m}$ mixed-D columns, with a Jasco 830-RI refractive index detector. $\mathrm{CHCl}_{3}$ was used as the eluent with a flow rate of $1 \mathrm{~mL} \mathrm{~min}{ }^{-1}$ and polystyrene standards were used for calibration.

Advancing and receding contact angles were measured on as-coated films using a FTA200 Camtel goniometer. Water and diiodomethane of the highest available purity were used as wetting liquids. Water static contact angles $\left(\theta_{\mathrm{w}}\right)$ were also measured on films at different immersion times in water at $0,1,4,7$ and 10 days.

NEXAFS experiments were carried out on as-coated films using the U7A NIST/Dow materials characterization end-station at the National Synchrotron Light Source (NSLS) at Brookhaven National Laboratory (BNL) (Paik et al. 2007). The X-ray beam was elliptically polarized (polarization factor of 0.85 ), with the electric field vector dominantly in the plane of the storage ring. The photon flux was approximately $10^{11}$ photons per second at a typical storage ring current of $750 \mathrm{~mA}$. A spherical grating monochromator was used to obtain monochromatic soft X-rays at an energy resolution of $0.2 \mathrm{eV}$. The C(1s) NEXAFS spectra were acquired for the incident photon energy in the range of $270-320 \mathrm{eV}$. The angle of incidence of the $\mathrm{X}$-ray beam, $\theta$ measured from the sample surface, was varied so as to check for molecular orientation on the surface layer and to permit a rough depth profiling. The partial-electron-yield (PEY) signal was collected using a channeltron electron multiplier with an adjustable entrance grid bias (EGB). Data reported used a grid bias of $-150 \mathrm{~V}$. The channeltron PEY detector was positioned at an angle of $36^{\circ}$ in the plane relative to the incident X-ray beam (Sohn et al. 2009). The PEY C(1s) spectra were normalized by subtracting the linear pre-edge baseline and setting the edge jump to unity at $320 \mathrm{eV}$ (Samant et al. 1996). The photon energy was calibrated by adjusting the peak position of the lowest $\pi^{*}$ phenyl resonance from polystyrene to $285.5 \mathrm{eV}$.

\section{XPS measurements were performed}




\section{Settlement test and measure of removal force of attached organisms}

\section{Barnacle culture}

Settlement assays, removal by hydrodynamic shear and removal by push-off were performed with cypris larvae, juveniles and adults of Balanus amphitrite, respectively. Prior to tests, the films were leached to remove residual chemicals by immersion in a container with MilliQ water with a circulating system comprising a pump and filters (with activated carbon). After three months of leaching, surfaces were gently cleaned using a sponge in order to remove biofilm and contact angle measurements were repeated to ensure that the period of immersion did not change the surface wettability.

Adult broodstock was supplied by the Duke University Marine Laboratory, North Carolina, USA, and reared at Newcastle University. Adults were maintained in semistatic culture, in natural seawater (exchanged daily), at $23 \pm 2{ }^{\circ} \mathrm{C}$ and a salinity of 32 . Nauplius larvae were released naturally and attracted to a point cold light source. Nauplii were stored in a beaker with a dilute concentration of Tetraselmis suecica until approximately 10,000 stage 1 nauplii had been collected (within 2-3 h), as described in Elbourne et al. (2008). Nauplii were then transferred into a bucket with $10 \mathrm{~L}$ of $0.7 \mu \mathrm{m}$

filtered seawater, $36.5 \mathrm{mg} \mathrm{L}^{-1}$ of streptomycin sulphate and $21.9 \mathrm{mg} \mathrm{L}^{-1}$ of penicillin $\mathrm{G}$ and incubated at $28^{\circ} \mathrm{C}$. The larvae were fed daily with an excess of Tetraselmis suecica and Skeletonema marinoi until metamorphosis to the cyprid. Cyprids for settlement assays were collected by filtration and stored in $0.22 \mu \mathrm{m}$ filtered natural seawater (FSW) at $6^{\circ} \mathrm{C}$ for 3 days. After settlement assays, metamorphosed cyprids were cultured on the coated glass slides for 7 days before testing for ease of release in a fully turbulent flow cell. The juveniles were grown in $15 \mathrm{~mL}$ of FSW containing $T$. suecica. The water was changed and new food added every two days. Simultaneously, with the same set of surfaces, juveniles were grown for six weeks on a diet of $T$. suecica, at $28^{\circ} \mathrm{C}$ and a photoperiod of $12 \mathrm{~h}: 12 \mathrm{~h}$ light:dark until the base of barnacles reached $2 \mathrm{~mm}$ in diameter. The diet was then switched to freshly hatched Artemia sp. for a further six weeks at which point the barnacles had attained a basal diameter of between 5 and $15 \mathrm{~mm}$. During culture, the position of the barnacles was monitored and barnacles were removed as necessary to ensure that none were in contact so that they grew with regular basal 
margins and that the measurements of adhesion strength were done with individual barnacles.

\section{Settlement assay}

Settlement assays were carried out using coated glass slides placed in quadriPERM dishes (Sarstedt, Germany). Approximately $20 \times 3$-day-old cyprids were placed in a $1 \mathrm{~mL}$ drop of $0.22 \mu \mathrm{m}$ FSW onto the surface of each coated slide, with six replicates per formulation. The lids were placed on the quadriPERM dishes to minimise water evaporation and incubated in the dark at $28^{\circ} \mathrm{C}$. Settlement was enumerated after 24 and $48 \mathrm{~h}$ and expressed as percentage settlement. Polystyrene 24-well plates, containing $2 \mathrm{~mL}$ of $0.22 \mu \mathrm{m} \mathrm{FSW}$ and 15 cyprids per well ( $\mathrm{n}=6$ replicates), were used as a reference to check cyprid health and that settlement was at normal levels.

\section{Flow cell}

Removal of permanently attached juveniles (7 days post metamorphosis) from coated slides ( $\mathrm{n}=6$ per formulation) by hydrodynamic shear was carried out using a fully turbulent flow cell at Newcastle University (Callow et al. 2014). The flow cell simulates the turbulent boundary layer created by ships when underway. Juvenile barnacles on the coated slides were located, counted and exposed to a shear stress of $120 \mathrm{~Pa}$ for 40 seconds. Juveniles still anchored on the slides were located and counted.

\section{Critical removal stress (adhesion strength)}

Approximately $50 \times 3$-day-old cyprids were placed onto the coated slides to ensure that sufficient numbers of adults developed for adhesion strength measurements. Six replicates were used per coating. The adhesion strength measurements were made on 12week-old barnacles on the second set of surfaces using a custom-built, fully-automated instrument (Advanced Analysis and Integration Ltd, Manchester, UK) as described in Conlan et al. (2008). Briefly, the instrument was equipped with a camera to photograph the barnacle bases. Computer software calculated the basal area in $\mathrm{mm}^{2}$. The coated slides, attached to a platform, were moved towards a bar, which removed them from the surface. The force applied to remove the barnacles was calculated using an electric load 
cell previously calibrated to convert the output to a force. Finally, the critical removal stress was automatically computed as force per unit area $\left(\mathrm{N} \mathrm{mm}^{-2}\right)$ of the barnacle basis.

\section{Data analysis}

Results related to settlement, flow cell and push-off tests are presented as means \pm standard error (SE). Settlement assays were examined by one-way analysis of variance (ANOVA) with Tukey pairwise comparisons using Minitab 15. An alpha level of 0.05 was accepted as significant.

\section{Algal assays}

Coated slides of each sample were placed in a 30-L tank of recirculating deionized water at $\sim 20^{\circ} \mathrm{C}$ for 7 days. Samples were equilibrated with artificial seawater (ASW: Tropic Marin ${ }^{\circledR}$ ) for $1 \mathrm{~h}$ prior to the start of the bioassays. Zoospores were released into ASW from mature plants of Ulva linza using a standard method (Callow et al. 1997; Thomé et al. 2012). In brief, $10 \mathrm{~mL}$ of zoospore suspension, adjusted to $1 \times 10^{6}$ spores $\mathrm{mL}^{-1}$ with ASW, were added to test surfaces (6 replicates of each coating type) placed in individual compartments of quadriPERM dishes (Greiner One), which were placed in darkness at room temperature. After $45 \mathrm{~min}$, the slides were washed in ASW to remove unsettled (unattached) zoospores. The slides with settled (attached) spores were cultured for the release assay.

Ten millilitres of enriched seawater medium (Starr and Zeikus 1987) were added to each compartment of the quadriPERM dishes, which were incubated at $18^{\circ} \mathrm{C}$ with a 16 $\mathrm{h}: 8 \mathrm{~h}$ light:dark cycle with a light intensity of $40 \mu \mathrm{mol} \mathrm{m} \mathrm{m}^{-2}$, for 7 days to allow the growth of sporelings (young plants). The medium was refreshed after $24 \mathrm{~h}$ and then every two days. Sporeling biomass was determined in situ by measuring the fluorescence of the chlorophyll contained within the cells with a fluorescence plate reader (Tecan Genios Plus), $\lambda$ excitation and emission: 430 and $670 \mathrm{~nm}$, respectively. The biomass was quantified in terms of relative fluorescence units (RFU) (Mieszkin et al. 2012).

The strength of attachment of sporelings was determined using a flow channel (Schultz et al. 2000, 2003) in which the slides were exposed to a wall shear stress of 20 
Pa. Percentage removal was calculated from readings taken before and after exposure to flow, with $95 \%$ confidence limits calculated from arcsine-transformed data.

\section{Results and Discussion}

The two block copolymers Si-EG and Si-AF were synthesized by atom transfer radical polymerization (ATRP) of the hydrophilic polyethyleneglycol methyl ether methacrylate (EG) and the hydrophobic/lipophobic 1H,1H,2H,2H-perfluorooctyl acrylate (AF), respectively, starting from a bromo-terminated PDMS macroinitiator (Si-Br) (Figure 1). $\mathrm{Si}-\mathrm{AF}$ and Si-EG were dispersed each at different loadings as surface-active components in a PDMS matrix to create antifouling/fouling release coatings.

\section{Figure 1}

\section{Preparation of PDMS-based films}

The devised films were prepared following a three-step procedure. A thin bottom PDMS layer $(\sim 2 \mu \mathrm{m})$ was first spray-coated on a glass slide. Condensation between the silanol groups of PDMS and the glass surface formed a cross-linked network film and ensured its firm covalent anchorage to the substratum, thereby preventing delamination during underwater evaluations. A thick middle PDMS layer $(\sim 200 \mu \mathrm{m})$ was then cast on top of it to secure bonding. This middle layer was necessary to impart the desired bulk thickness and elastic modulus to the overall system. A relatively large thickness (150-200 $\mu \mathrm{m})$ and a low elastic modulus $(E<\sim 2 \mathrm{MPa}$ ) have been shown to favour the release of several macrofoulers, including U. linza (Chaudhury 2005). Previous PDMS-based films composed of the same thick middle layer as that of this work exhibited tensile modulus values as low as $0.2 \mathrm{MPa}$ (Yasani et al. 2014). Finally, a thin top layer $(\sim 2 \mu \mathrm{m})$ of the PDMS matrix blended with the surface-active copolymer, Si-EG or Si-AF (4 and $8 \mathrm{wt} \%$ with respect to PDMS), was spray-coated to provide the desired surface properties. In fact, the incorporation of low amounts of copolymer in the top layer has been demonstrated not to significantly affect the elastomeric character of the entire film (Marabotti et al. 2009). Therefore, the dispersed copolymer is ultimately responsible for the surface and interface properties of the final film only. According to this strategy, the surface-active copolymer was physically embedded, ie not chemically linked, within the 
PDMS network matrix. The Si block improved the chemical compatibility of both block copolymers with the PDMS matrix and homogeneous transparent films were obtained at any of the loadings investigated.

In all of the three steps, the cross-linking reactions of PDMS occurred at room temperature via a condensation sol-gel process that was catalyzed by BiND. This catalyst has recently been shown to be less toxic than tin-based catalysts in laboratory assays against several marine species (Pretti et al. 2013). Final cure was carried out at $120^{\circ} \mathrm{C}$ to facilitate the block copolymer migration to the film surface. Polymer leaching out of the films was never observed in extraction experiments with water.

\section{Contact angle measurements}

Table 1 shows the advancing $\left(\theta^{a}\right)$ and receding $\left(\theta^{r}\right)$ contact angles of water and diidomethane on the four PDMS-based films that were used in the biofouling assays. Also included are the contact angles measured on the PDMS control. All the films were hydrophobic and lipophobic, as the advancing contact angles with water $\left(\theta_{\mathrm{w}}{ }^{\mathrm{a}}\right)$ and diiodomethane $\left(\theta_{\mathrm{di}}^{\mathrm{a}}\right)$ were higher than $100^{\circ}$ and $70^{\circ}$, respectively. Furthermore, films containing the fluorinated copolymer Si-AF showed $\theta_{\mathrm{w}}{ }^{\mathrm{a}}$ and $\theta_{\mathrm{di}}{ }^{\mathrm{a}}$ higher than those having the oxyethylene copolymer Si-EG, which exhibited $\theta_{\mathrm{w}}{ }^{\mathrm{a}}$ and $\theta_{\mathrm{di}}{ }^{\mathrm{a}}$ values similar to those of pristine PDMS. These results suggest that the Si-AF_w surfaces were enriched by the fluorinated block of the copolymer, while in Si-EG_w films the EG block was weakly surface segregated and the siloxane component preferentially populated the surface.

All the films showed a significant hysteresis $\left(\theta^{a}-\theta^{\mathrm{r}} \approx 40-95^{\circ}\right)$. It is generally accepted that contact angle hysteresis is mainly caused by surface roughness, chemical heterogeneity of the topmost layer, and surface reconstruction of the polymer film after contact with the liquid (Good 1992). Si-EG_w films and the PDMS reference displayed similar hysteresis values, comparable to literature values for related polymer films (Hoipkemeier-Wilson et al. 2004) possibly due to surface reconstruction of silicone when in contact with water (Uilk et al. 2002). The reconstruction process of PDMS consists of the rotation of the hydrophobic $-\mathrm{CH}_{3}$ moieties and reorientation of the flexible backbone which drives the polar $\mathrm{Si}-\mathrm{O}$ groups to contact with water. On the other hand, the $\mathrm{Si}$ AF_w films displayed a greater difference between the advancing and receding water 
contact angles. This result is unexpected because fluorinated polymers are generally known to be more stable upon contact with water, owing to their low surface energy. However, for complex systems such as those described here, surface heterogeneity due to segregation of the surface-active copolymer within the PDMS matrix may result in a comparatively large hysteresis. Water static contact angles $\left(\theta_{\mathrm{w}}\right)$ were also measured. It was found that for PDMS-based films containing an Si-EG copolymer with varied EG content (up to $44 \mathrm{EG}$ repeat units, $\theta_{\mathrm{w}} \leq 113^{\circ} \pm 1^{\circ}$ ) or an Si-AF copolymer with varied $\mathrm{AF}$ content (up to $50 \mathrm{AF}$ repeat units, $\theta_{\mathrm{w}} \leq 110^{\circ} \pm 1^{\circ}$ ) at varied loadings (up to $10 \mathrm{wt} \%$ ) at different times of immersion in water the $\theta_{\mathrm{w}}$ decreased very little, $2^{\circ} \pm 1^{\circ}$ and $4^{\circ} \pm 2^{\circ}$ after 10 days, respectively (data not shown). This suggests that surface reconstruction was minor for the Si-EG_w and Si-AF_w films at these copolymer loadings and that surface chemical heterogeneity was mainly responsible for the dynamic contact angle hysteresis.

In order to gain a better understanding of the chemical composition of the film surfaces, NEXAFS experiments were carried out on Si-EG_w and Si-AF_w films and XPS experiments were performed on Si-AF_w films.

\section{Table 1}

\section{NEXAFS and XPS analyses}

Surface composition and molecular orientation in the outermost $3 \mathrm{~nm}$ of the polymer surface were investigated by NEXAFS spectroscopy. The NEXAFS spectra of the oxyethylene and fluoroalkyl PDMS-based films are reported in Figure 2 and compared with pristine PDMS.

For both sets of films, there are a prominent peak at $288 \mathrm{eV}$ attributed to the $1 \mathrm{~s} \rightarrow \sigma^{*} \mathrm{C}-\mathrm{H}$ resonance and a broad peak at $292 \mathrm{eV}$ attributed to the $1 \mathrm{~s} \rightarrow \sigma^{*}{ }_{\mathrm{C}-\mathrm{Si}}$ resonance from the PDMS. In addition to these signals, the peak at $289.5 \mathrm{eV}$ is assigned to the $1 \mathrm{~s} \rightarrow \pi^{*} \mathrm{C}=\mathrm{O}$ resonance from the ester of the acrylate group along with the peak at $300 \mathrm{eV}$ due to an additional $\mathrm{C}=\mathrm{O}$ resonance (Figure 2 bottom). The $\sigma^{*}{ }_{\mathrm{C}-\mathrm{F}}$ and $\sigma^{*}{ }_{\mathrm{C}-\mathrm{C}}$ resonances of the fluoroalkyl group produce peaks at $294 \mathrm{eV}$ and $299 \mathrm{eV}$, respectively (Figure 2 bottom). In any case, the continuum step from carbon was found to be around $287 \mathrm{eV}$. 


\section{Figure 2}

Comparing PDMS to Si-EG_w, it can be seen that there is an enrichment of C-C bonds from the EG component at the surface based on the appearance of peaks at $297 \mathrm{eV}$ (Figure 2 top). Moreover, a small broad peak is visible for Si-EG_w at $293 \mathrm{eV}$ from the $1 \mathrm{~s} \rightarrow \sigma^{*}{ }_{\mathrm{C}-\mathrm{O}}$ resonance. However, there are no significant differences between Si-EG_4 and Si-EG_8, indicating that the loading of the block copolymer does not change the surface population of EG in these experiments.

The differences between PDMS and Si-AF_w are more dramatic (Figure 2 bottom). There is a major decrease in the peak at $288 \mathrm{eV}$, indicating much less PDMS at the surface. Additionally, there is a significant surface segregation of the AF block based on the appearance of peaks associated with the $\mathrm{C}-\mathrm{F}$ bonds at $294 \mathrm{eV}$, the $\mathrm{C}=\mathrm{O}$ bonds of the AF units at $289.5 \mathrm{eV}$, and $\mathrm{C}-\mathrm{C}$ bonds at $297 \mathrm{eV}$ and $299 \mathrm{eV}$. The difference between Si-AF_4 and Si-AF_8 is small, though it is clear from peaks at $294 \mathrm{eV}$ and $288 \mathrm{eV}$ that the latter has a higher surface population of the AF block, showing a surface effect from the loading ratio difference between these two samples.

\section{Figure 3}

The $\sigma^{*}$ C-F peak showed an angle dependence, suggesting orientation relative to the plane of the surface (Figure 3). The intensity of the peak increased with increasing angle $\theta$ indicating that the orientation of the $\mathrm{C}-\mathrm{F}$ bond was perpendicular to the surface normal. Thus, the fluoroalkyl side chains extend upward towards the surface, normal to the surface. Additionally, the increase in peaks associated with the $\mathrm{C}-\mathrm{F}$ bonds in the spectra at $\theta=120^{\circ}$ for both Si-AF_4 and Si-AF_8 showed that there was an enrichment of the AF block in the top $3 \mathrm{~nm}$ of the surface, as the block copolymer was strongly surface segregating. Therefore, NEXAFS analysis shows that, although PDMS is the major component in the Si-AF_w blends, the surface of the polymer films is highly fluorinated.

This conclusion was further confirmed by XPS analysis performed on Si-AF_w films. XPS survey spectra in the binding energy range $0-800 \mathrm{eV}$ were recorded prior and 
after immersion (3 days) in water for Si-AF_w films at the photoemission angle $\phi$ of $70^{\circ}$ with the aim of ascertaining whether the surface of the films could reorganize in response to the different outer environment. The experimental data for the atomic surface compositions from the signals centred at $\sim 153 \mathrm{eV}(\mathrm{Si}(2 \mathrm{~s})), \sim 290 \mathrm{eV}(\mathrm{C}(1 \mathrm{~s})), \sim 533 \mathrm{eV}$ $(\mathrm{O}(1 \mathrm{~s}))$ and $\sim 689 \mathrm{eV}(\mathrm{F}(1 \mathrm{~s}))$ are summarized in Table 2, where they are also compared with the theoretical values calculated on the basis of known chemical composition. For both dry films, it was found that the surface was highly enriched in F content with respect to the theoretical value, eg 55\% vs $1 \%$ for Si-AF_8, whereas the Si content was much lower than expected, eg 4\% vs $24 \%$ for Si-AF_8. After being immersed in water the surfaces displayed quite similar values of element abundance as the respective dry films, and in particular the F content was as much as more than $50 \%$. One notes that the surface composition of the films after immersion is that corresponding to a kinetically trapped condition, rather than the equilibrium state when in contact with water. The XPS spectra of the surface after immersion can, therefore, be considered indicative of the chemical composition when the surface is in contact with water. Nonetheless, the XPS findings confirm the rich population of the film surface by the AF block of the surface-active copolymer which makes the film surface chemically heterogeneous.

Table 2. XPS atomic surface concentrations $\left(\phi=70^{\circ}\right)$ for the Si-AF_w films before and after immersion in water.

\begin{tabular}{|c|c|c|c|c|c|}
\hline \multirow{2}{*}{ Sample } & & $\begin{array}{c}\mathrm{F} \\
(\%)\end{array}$ & $\begin{array}{c}\mathrm{O} \\
(\%)\end{array}$ & $\begin{array}{c}\mathrm{C} \\
(\%)\end{array}$ & $\begin{array}{c}\mathrm{Si} \\
(\%)\end{array}$ \\
\hline \multirow{3}{*}{ Si-AF_4 } & theoretical & $\sim 1$ & 25 & 50 & 24 \\
\cline { 2 - 6 } & before & 52 & 10 & 34 & 4 \\
\cline { 2 - 6 } & after & 53 & 9 & 34 & 4 \\
\hline \multirow{3}{*}{ Si-AF_8 } & theoretical & 1 & 24 & 51 & 24 \\
\cline { 2 - 6 } & before & 55 & 9 & 32 & 4 \\
\cline { 2 - 6 } & after & 53 & 10 & 34 & 3 \\
\hline
\end{tabular}

In addition, according to NEXAFS the perfluoroalkyl segments of the AF block display a certain degree of order at the polymer-air interface. This finding is in agreement with that previously reported for poly(perfluorooctyl acrylate) films in which the surface 
segregation of the fluoroalkyl chains led to a significant order at the surface, despite the amorphous nature of the bulk phase (Lüning et al. 2001). In contrast, no angle dependence was seen in the spectra for Si-EG_w, showing both an absence of surface orientation of the surface segregated EG chains and no changes in the chemical composition of these film surfaces throughout the top $3 \mathrm{~nm}$.

\section{Attachment strength of sporelings of $U$. linza}

All test surfaces were successfully colonised by spores and after 7 days they were all covered with a green lawn of sporelings. The percentage biomass removed by exposure to a $20 \mathrm{~Pa}$ wall shear stress is shown in Figure 4. Sporelings were attached much less strongly to Si-EG_w films compared to Si-AF_w (one-way ANOVA on arcsine transformed data with Tukey test F 4, $23=69.7 p<0.05$ ). An improvement in the release of sporelings was seen when the percentage of Si-EG copolymer was increased from SiEG_4 to Si-EG_8. In the case of fluorinated films, the percentage removal of biomass was similar for 4 and $8 \mathrm{wt} \%$ loadings and was not significantly different from the PDMS control.

The results suggest that PDMS films containing the oxyethylene copolymer performed much better $(\sim 60-90 \%)$ than the corresponding films with the fluorinated copolymer $(\sim 15 \%)$, possibly due to a more hydrophilic nature imparted by the Si-EG block copolymer. This is in agreement with previous studies on styrene-based surfaceactive random copolymers with hydrophilic and hydrophobic side chains (Yasani et al. 2014). In that study the fluorine-free oxyethylene-containing copolymers also showed superior fouling-release properties against $U$. linza, even though the shear stress required to obtain the same removal was more than doubled.

\section{Figure 4}

\section{Settlement of barnacle cyprids}

Settlement of cyprids after $48 \mathrm{~h}$ was markedly higher on films with the oxyethylene copolymer (Si-EG_4 $=15.8 \%$ and Si-EG_8 $=21.7 \%$ ) than films with the fluoroalkyl copolymer (Figure 5), for which no settlement was detected. This result is in agreement 
with previous studies that have shown that fluorinated surfaces strongly inhibit barnacle settlement. For example, Tsibouklis et al. (2000) reported that B. amphitrite cyprid settlement was lower on perfluoroalkyl polymers compared to on PDMS surfaces. Mera and Wynne (2001) demonstrated the efficacy of a self-curable fluorinated silicone resin cross-linked with a non-fluorinated polysiloxane resin. Moreover, Webster et al. (2009) observed that settlement of cyprids was reduced by surface-active fluorinated/siloxane copolymers as compared to PDMS.

The films containing Si-EG performed better than the PDMS control in inhibiting settlement after $48 \mathrm{~h}(\mathrm{p}=0.000, \mathrm{~F}=45.28, \mathrm{df}=5)$ but not at $24 \mathrm{~h}$. Although Si-EG_4 had fewer settled larvae than Si-EG_8 (Figure 5), this difference was not significant. Tukey test pairwise comparisons are presented in Figure 5. This effect of oxyethylene chains is consistent with previous studies of barnacle settlement on PEG-based hydrogels (Ekblad et al. 2008).

The anti-settlement effects were achieved with no significant mortality compared to the polystyrene standard (data not shown).

\section{Figure 5}

\section{Adhesion strength of juvenile barnacles}

Attached larvae were grown on for 7 days post-metamorphosis to the juvenile barnacle. The ease of removal test for juveniles was performed only on PDMS and the Si-EG_w coatings on which cyprids settled. The percentage removal by exposure to a $120 \mathrm{~Pa}$ wall shear stress in the flow channel is shown in Figure 6. Although removal was higher for Si-EG_4 than Si-EG_8, this difference was not significant. The presence of the surfaceactive Si-EG copolymer appeared to lead to an improvement in the performance with respect to the pristine PDMS, although these differences were not significant either $(\mathrm{p}=$ $0.068, \mathrm{~F}=3.01, \mathrm{df}=2$ ).

\section{Figure 6}

\section{Adhesion strength of adult barnacles}


Only barnacles with base plates $>5 \pm 1 \mathrm{~mm}$ were considered for this test. The relatively high number of cyprids added to surfaces, compared to the juvenile removal assay, led to some settlement on Si-AF_4 but there was still none on Si-AF_8. The critical removal stress required to detach adult barnacles was generally low $\left(0.025-0.045 \mathrm{~N} \mathrm{~mm}^{-2}\right)$ on all the experimental films, including the PDMS control (Figure 7) and lower than that measured for previous, PDMS-based films that had been cured by a tin-based catalyst (Marabotti et al. 2009; Martinelli et al. 2012b). This may be due to the lower elastic moduli of the present bismuth-catalyst cured PDMS matrix, which affects the adhesion strength of adult barnacles (Brady and Singer 2000).

Adult barnacles attached less strongly to Si-EG_4 and Si-AF_4 compared to PDMS. The adhesion strength was relatively high, however, for Si-EG_8 with the highest content of oxyethylene copolymer $(\mathrm{p}=0.000, \mathrm{~F}=7.85, \mathrm{df}=3)$. The trend of slightly stronger adhesion to Si-EG_8 compared to Si-EG_4 is, therefore, consistent for both juveniles and adults. Adult barnacles adhered more strongly to Si-EG_8 than to PDMS, a result in contrast to that obtained with juveniles.

\section{Figure 7}

\section{Concluding remarks}

Well-defined block copolymers composed of a polysiloxane first block and a poly(meth)acrylate second block with different hydrophilic oxyethylene or hydrophobic/lipophobic fluoroalkyl side chains were synthesized by ATRP and dispersed as surface-active components in a cross-linked PDMS matrix (4 and $8 \mathrm{wt} \%$ loadings). The wettability, surface composition and antifouling/fouling-release performance of the two systems with different hydrophilicity/phobicity were compared, so that correlations were found between the surface chemistry of films and their biological response against two macrofoulants. Specifically, fluorine-free PDMS-based films with surfaces consisting of polysiloxane and oxyethylene chains as the majority and minority components, respectively, exhibited good fouling-release properties against sporelings of $U$. linza and juveniles of B. amphitrite. On the other hand, PDMS-based films with surfaces highly enriched in fluorinated chains had superior antifouling properties with no 
cyprids of $B$. amphitrite settling on them under the settlement protocol adopted. Settlement of very few cyprids was only observed under forced settlement on the fluorinated film Si-AF_4. Thus, a different and noteworthy activity against two of the most common fouling macroorganisms at the different stages of their life cycles was effected by varying the nature of the surface-active polymer in these PDMS-based films. Previous investigations have highlighted the potential for marine application of amphiphilic polymer coatings containing both hydrophilic oxyethylene and hydrophobic fluoroalkyl side chain polymers in which the film surface responded to the outer environment and experienced a reconstruction upon immersion in water (Krishnan et al. 2006, Martinelli et al. 2008). Our ongoing studies aim at assessing the capability of PDMS-based films with an amphiphilic surface-active copolymer composed of mixed oxyethylene and fluoroalkyl side chains to undergo surface reconstruction in view of a broad-spectrum biological activity.

\section{Acknowledgements}

Work supported by the EC Framework 7 SEACOAT project (Surface Engineering for Antifouling: Coordinated Advanced Training, contract 237997) and the University of Pisa (PRA fondi 2015). Use of the National Synchrotron Light Source, Brookhaven National Laboratory, was supported by the U.S. Department of Energy, Office of Science, Office of Basic Energy Sciences, under Contract No. DE-AC02-98CH10886.

\section{References}

Aldred N, Clare AS. 2008. Mini-review: The adhesive strategies of cyprids and development of barnacle-resistant marine coatings. Biofouling. 24:351-363.

Beigbeder A, Degee P, Conlan SL, Mutton R, Clare AS, Pettitt ME, Callow ME, Callow JA, P Dubois. 2008. Preparation and characterization of silicone-based coatings filled with carbon nanotubes and natural sepiolite and their application as marine fouling-release coatings. Biofouling. 24:291-302.

Berglin M, Gatenholm P. 1999. The nature of bioadhesive bonding between barnacles and fouling release silicone coatings. J Adhesion Sci Technol. 13:713-727.

Bianco M, Guarino V, Maruccio G, Galli G, Martinelli E, Montani G, Rinaldi R, Arima V. 2015. Non-biofouling fluoropolymer coatings for contact lenses, Sci Adv Mater. 7:1387-1394.

Brady RF, Singer IL. 2000. Mechanical factors favoring release from fouling release coatings. Biofouling. 15:73-81.

Callow ME, Callow JA, Pickett-Heaps JD, Wetherbee R. 1997. Primary adhesion of Enteromorpha (Chlorophyta, Ulvales) propagules: quantitative settlement studies and video microscopy. J Phycol. 33:938-947.

Callow JA, Callow ME. 2006. Biological Adhesives. Berlin, Heidleberg: Springer-Verlag. Chapter 4, The Ulva spore adhesive system; pp. 63-78. 
Callow ME, Callow JA, Conlan S, Clare AS, Stafslien S. 2014. Efficacy testing of nonbiocidal and fouling-release coatings. In: Dobretsov S, Williams DN, Thomason J, Eds. Biofouling Methods. Chichester: Wiley-Blackwell, pp.291-316.

Cassé F, Stafslien SJ, Bahr JA, Daniels J, Finlay JA, Callow JA, Callow ME. 2007. Combinatorial materials research applied to the development of new surface coatings V. Application of a spinning water-jet for the semi-high throughput assessment of the attachment strength of marine fouling algae. Biofouling. 23:121-130.

Chaudhury MK, Finlay JA, Chung JY, Callow ME, Callow JA. 2005. The influence of elastic modulus and thickness on the release of the soft-fouling green alga Ulva linza (syn. Enteromorpha linza) from poly(dimethylsiloxane) (PDMS) model networks. Biofouling. 21:41-48.

Cho Y, Sundaram HS, Weinman CJ, Paik MY, Dimitriou MD, Finlay JA, Callow ME, Callow JA, Ober CK, Kramer EJ. 2011. Triblock copolymers with grafted fluorine-free, amphiphilic, non-ionic side chains for antifouling and fouling-release applications. Macromolecules. 44:4783-4792.

Clare AS, Matsumura, K. 2000. Nature and perception of barnacle settlement pheromones. Biofouling. 15:57-71.

Clare AS, Hoeg JT. 2008. Balanus amphitrite or Amphibalanus amphitrite? A note on barnacle nomenclature. Biofouling 24: 55-57.

Clare AS, Aldred N. 2009. Surface colonization by marine organisms and its impact on antifouling research. In: Hellio C, Yebra DM, Eds. Advances in Marine Antifouling Coatings and Technologies. Cambridge: Woodhead Publishing Ltd, pp.46-79.

Conlan SC, Mutton RJ, Aldred N, Clare AS 2008. Evaluation of a fully automated method to measure the critical removal stress of adult barnacles. Biofouling. 24:471-481.

Duong TH, Briand JF, Margaillan A, Bressy C. 2015. Polysiloxane-based block bopolymers with marine bacterial anti-adhesion properties. ACS Appl Mater Interfaces. 7:15578-15586. Ekblad T, Bergström G, Ederth T, Conlan SL, Mutton R, Clare AS, Wang S, Liu Y, Zhao Q, D’Souza F, Donnelly GT, Willemsen PR, Pettitt ME, Callow ME, Callow JA, Liedberg B. 2008. Poly(ethylene glycol)-containing hydrogel surfaces for antifouling applications in marine and freshwater environments. Biomacromolecules 9: 2775-2783.

Elbourne PD, Veater RA, Clare AS. 2008. Interaction of conspecific cues in Balanus amphitrite Darwin (Cirripedia) settlement assays: continued argument for the single-larva assay. Biofouling. 24:87-96.

Evans LV. 2009. Editor's note. Biofouling 25:81.

Flemming HC, Sriyutha Murthy P, Venkatesan R, Cooksey KS. 2009. Marine and Industrial Biofouling. Spinger, Los Angeles.

Fusetani N, Clare AS (eds). 2006. Antifouling compounds. Progress in Molecular and Subcellular Biology vol. 42. Berlin: Springer-Verlag.

Good, RJ. 1992. Contact angle, wetting, and adhesion: A critical review. J Adhes Sci Technol. 6:1269-1302.

Gudipati CS, Greenlief CM, Johnson JA, Prayongpan P, Wooley KL. 2004. Hyperbranched fluoropolymer and linear poly(ethyleneglycol) based amphiphilic cross-linked networks as efficient antifouling coatings: An insight into the surface compositions, topographies and morphologies. J Polym Sci Part A: Polym Chem. 42:6193-6208.

Hoipkemeier-Wilson L, Schumacher JF, Carman ML, Gibson AL, Feinberg AW, Callow ME, Finlay JA, Callow JA, Brennan AB. 2004. Antifouling potential of lubricious, microengineered, PDMS elastomers against zoospores of the green fouling alga Ulva (Enteromorpha). Biofouling. 20:53-63.

Huan K, Bes L, Haddleton DM, Khoshdel E. 2001. Synthesis and properties of polydimethylsiloxane-containing block copolymers via living radical polymerization. J Polym Sci Part A: Polym Chem. 39:1833-1842. 
Imbesi PM, Finlay JA, Aldred N, Eller MJ, Felder SE, Pollack KA, Lonnecker AT, Raymond JE, Mackay ME, Schweikert EA, Clare AS, Callow JA, Callow ME, Wooley KL. (2012) Targeted surface nanocomplexity: Two-dimensional control over the composition, physical properties and anti-biofouling performance of hyperbranched fluoropolymer-poly(ethylene glycol) amphiphilic crosslinked networks. Polym Chem. 3: 3121-3131.

Kania RE, Lamers GEM, van de Laar N, Dijkhuizen M, Lagendijk E, Huy PTB, Herman P, Lemstra PH, Grote JJ, Frijns J, Bloemberg GV. 2010. Biofilms on tracheoesophageal voice prostheses: a confocal laser scanning microscopy demonstration of mixed bacterial and yeast biofilms. Biofouling. 26:519-526.

Kavanagh CJ, Swain GW, Kovach BS, Stein J, Darkangelo-Wood C, Truby K, Holm E, Montemarano J, Meyer A, Weibe D. 2003. The effects of silicone fluid additives and silicone elastomer matrices on barnacle adhesion strength. Biofouling 19: 381-390.

Kavanagh CJ, Quinn RD, Swain GW. 2005. Observations of barnacle detachment from silicones using high-speed video. J Adhes. 81:843-868.

Kim J, Chisholm BJ, Bahr J. 2007. Adhesion study of silicone coatings: The interaction of thickness, modulus, and shear rate on adhesion force. Biofouling. 23:113-120.

Kim J, Nyren-Erikson E, Stafslien S, Daniels J, Bahr J, Chisholm BJ. 2008. Release characteristics of reattached barnacles to non-toxic silicone coatings. Biofouling. 24:313319.

Krishnan S, Wang N, Ober CK, Finlay JA, Callow ME, Callow JA, Hexemer A, Sohn KE, Kramer EJ, Fischer DA. 2006. Comparison of the fouling release properties of hydrophobic fluorinated and hydrophilic PEGylated block copolymer surfaces: Attachment strength of the diatom Navicula and the green alga Ulva. Biomacromolecules. 7:1449-1462.

Leroy C, Delbarre C, Ghillebaert F, Compere C, Comber D. 2008. Effects of commercial enzymes on the adhesion of a marine biofilm-forming bacterium. Biofouling 24: 11-22.

Long CJ, Schumacher JF, Robinson P.A.C., Finlay JA, Callow ME, Callow JA, Brennan AB. 2010. A model that predicts the attachment behavior of Ulva linza zoospores on surface topography. Biofouling. 26: 411-419.

Lüning J, Stöhr J, Song KY, Hawker CJ, Iodice P, Nguyen CV, Yoon DY. 2001. Correlation of surface and bulk order in low surface energy polymers. Macromolecules 34:1128-1130.

McMaster DM, Bennett SM, Tang Y, Finlay JA, Kowalke GL, Nedved B, Bright FV, Callow ME, Callow JA, Wendt DE, Hadfield MG, Detty MR. 2009. Antifouling character of 'active' hybrid xerogel coatings with sequestered catalysts for the activation of hydrogen peroxide. Biofouling 25: 21-33.

Majumdar P, Lee E, Patel N, Ward K, Stafslien SJ, Daniels J, Boudjouk P, Callow ME, Callow JA, Thompson SEM. 2008. Combinatorial materials research applied to the development of new surface coatings IX: An investigation of novel anti-fouling/fouling-release coatings containing quaternary ammonium salt groups. Biofouling. 24:185-200.

Marabotti I, Morelli A, Orsini LM, Martinelli E, Galli G, Chiellini E, Lien EM, Pettitt ME, Callow ME, Callow JA, Conlan SL, Mutton RJ, Clare AS, Kocijan A, Donik C, Jenko M. 2009. Fluorinated/siloxane copolymer blends for fouling release: chemical characterisation and biological evaluation with algae and barnacles. Biofouling. 25:481-493.

Martinelli E, Agostini S, Galli G, Chiellini E, Glisenti A, Pettitt ME, Callow ME, Callow JA, Graf K, Bartels F. 2008. Nanostructured films of amphiphilic fluorinated block copolymers for fouling release application. Langmuir. 24:13138-13147.

Martinelli E, Suffredini M, Galli G, Glisenti A, Pettitt ME, Callow ME, Callow JA, Williams D, Lyall G. 2011a. Amphiphilic block copolymer/poly(dimethylsiloxane) (PDMS) blends and nanocomposites for improved fouling-release. Biofouling. 27:529-541.

Martinelli E, Galli G, Krishnan S, Paik MY, Ober CK, Fischer DA. 2011b. New poly(dimethylsiloxane)/poly(perfluorooctylethyl acrylate) block copolymers: structure and order across multiple length scales in thin films. J Mater Chem. 21:15357-15368. 
Martinelli E, Sarvothaman MK, Alderighi M, Galli G, Mielczarski E, Mielczarski J. 2012a. PDMS network blends of amphiphilic acrylic copolymers with poly(ethylene glycol)fluoroalkyl side chains for fouling release coatings. I. Chemistry and stability of the film surface. J Polym Sci A: Polym Chem. 50:2677-2686.

Martinelli E, Sarvothaman MK, Galli G, Pettitt ME, Callow ME, Callow JA, Conlan SL, Clare S A, Sugiharto AB, Davies C, Williams D. 2012b. Poly(dimethyl siloxane) (PDMS) network blends of amphiphilic acrylic copolymers with poly(ethylene glycol)-fluoroalkyl side chains for fouling-release coatings. II. Laboratory assays and field immersion trials. Biofouling 28:571-582.

Martinelli E, Pelusio G, Yasani BR, Glisenti A, Galli G. 2015a. Surface chemistry of amphiphilic polysiloxane/triethyleneglycol-modified poly(pentafluorostyrene) block copolymer films before and after water immersion. Macromol Chem Phys. DOI: 10.1002/macp.201500221.

Martinelli E, Del Moro I, Galli G, Barbaglia M, Bibbiani C, Mennillo E, Oliva M, Pretti C, Antonioli D, Laus M. 2015b. Photo-polymerized network polysiloxane films with dangling hydrophilic/hydrophobic chains for the biofouling release of invasive marine serpulid Ficopomatus enigmaticus. ACS Appl Mater Interfaces. 7:8293-8301.

Maruzzo D, Conlan S, Aldred N, Clare AS, Hoeg JT. 2011. Video observation of surface exploration in cyprids of Balanus amphitrite: the movements of antennular sensory setae. Biofouling 27:225-239.

Mera AE, Wynne KJ. 2001. Fluorinated silicone resin fouling release composition. US6265515.

Mieszkin S, Martin-Tanchereau P, Callow ME, Callow JA. 2012. Effect of bacterial biofilms formed on fouling-release coatings from natural seawater and Cobetia marina, on the adhesion of two marine algae, Biofouling 28:953-968.

Olsen SM, Pedersen LT, Laursen MH, Kiil S, Dam-Johansen K. 2007. Enzyme-based antifouling coatings: A review. Biofouling 23:369-383.

Paik M, Krishnan S, You F, Li X, Hexemer A, Ando Y. 2007. Surface organization, light-driven surface changes, and stability of semifluorinated azobenzene polymers. Langmuir. 23:5110-5119.

Park D, Weinman CJ, Finlay JA, Fletcher BR, Paik MY, Sundaram HS, Dimitriou MD, Sohn KE, Callow ME, Callow JA, Handlin DL, Willis CL, Fischer DA, Kramer EJ, Ober CK. 2010. Amphiphilic surface active triblock copolymers with mixed hydrophobic and hydrophilic side chains for tuned marine fouling-release properties. Langmuir. 26:9772-9781.

Phang Y, Aldred N, Clare AS, Callow JA, Vansco GJ. 2006. An in situ study of the nanomechanical properties of barnacle (Balanus amphitrite) cyprid cement using atomic force microscopy (AFM). Biofouling. 22:245-250.

Pretti C, Oliva M, Mennillo E, Barbaglia M, Funel M, Yasani BR, Martinelli E, Galli G. 2013. An ecotoxicological study on tin- and bismuth-catalysed PDMS based coatings containing a surface-active polymer. Ecotoxicol Environ Saf. 98:250-256.

Qian P-Y, Xu Y, Fusetani N. 2010. Natural products as antifouling compounds: recent progress and future perspectives. Biofouling 26:223-234.

Samant MG, Stohr J, Brown HR, Russel TP, Sands JM, Kumar SK. 1996. NEXAFS studies on the surface orientation of buffed polyimides. Macromolecules 29:8334-8342.

Scardino AJ, DeNys R. 2011. Mini-review: Biomimetic models and bioinspired surfaces for fouling control. Biofouling 27:73-86.

Schultz MP, Finlay JA, Callow ME, Callow JA. 2000. A turbulent channel flow apparatus for the determination of the adhesion strength of microfouling organisms. Biofouling. 15:243-251.

Schultz MP, Finlay JA, Callow ME, Callow JA. 2003. Three models to relate detachment of low form fouling at laboratory and ship scale. Biofouling 19:17-26.

Schultz MP, Bendick JA, Holm ER, Hertel WM. 2011. Economic impact of biofouling on a naval surface ship, Biofouling 27:87-98. 
Sohn KE, Dimitriou MD, Genzer J, Fischer DA, Hawker CJ, Kramer EJ. 2009. Determination of the electron escape depth for NEXAFS spectroscopy. Langmuir. 25:6341-6348.

Sommer S, Ekin A, Webster DC, Stafslien S, Daniels J, van der Wal LJ, Thompson SEY, Callow ME, Callow JA. 2010. A preliminary study on the properties and fouling-release performance of siloxane-polyurethane coatings prepared from poly(dimethylsiloxane) (PDMS) macromers. Biofouling 26:961-972.

Starr R, Zeikus J. 1987. UTEX - the culture collection of algae at the University of Texas at Austin, J. Phycol. 23:1-47.

Sundaram HS, Cho Y, Dimitriou MD, Weinman CJ, Finlay JA, Cone G, Callow ME, Callow JA, Kramer EJ, Ober CK. 2011. Fluorine-free mixed amphiphilic polymers based on PDMS and PEG side chains for fouling release applications. Biofouling. 27:589-602.

Swain GW, Griffith JR, Bultman JD, Vincent HL. 1992. The use of barnacle adhesion measurements for the field evaluation of non toxic foul release surfaces. Biofouling. 6:105114.

Tan BH, Hussain H, Chaw KC, Dickinson GH, Gudipati CS, Birch WR, Teo SLM, He C, Liu Y, Davis TP. 2010. Barnacle repellent nanostructured surfaces formed by the self-assembly of amphiphilic block copolymers. Polym Chem. 1:276-279.

Tasso M, Pettitt ME, Cordeiro AL, Callow ME, Callow JA, Werner C. 2009. Antifouling potential of Subtilisin A immobilized to maleic anhydride copolymer thin films. Biofouling. 25:505-516.

Thomas KV, Brooks S. 2010. The environmental fate and effects of antifouling paint biocides. Biofouling 26:73-88.

Thomé I, Pettitt ME, Callow ME, Callow JA, Grunze M, Rosenhahn A. 2012. Conditioning of surfaces by macromolecules and its implication for the settlement of zoospores of the green alga Ulva linza. Biofouling. 28:501-510.

Townsin RL. 2003. The ship hull fouling penalty. Biofouling. 19 (supplement):9-15.

Tsibouklis J, Nevell TG, Graham P, Stone M. 2000. 32nd WEGEMT School "Marine Coatings", 10-14 July.

Uilk JM, Mera AE, Fox RB, Wynne KJ. 2002. Hydrosilation-cured poly(dimethylsiloxane) networks: intrinsic contact angles via dynamic contact angle analysis. Macromolecules. 36:3689-3694.

Walker G. 1981. The adhesion of barnacles. J Adhesion. 12:51-58.

Wang Y, Pitet LM, Finlay JA, Brewer LH, Cone G, Betts DE, Callow ME, Callow JA, Wendt DE, Hillmyer MA, De Simone JM. 2011. Investigation of the role of hydrophilic chain length in amphiphilic perfluoropolyether/poly(ethylene glycol) networks: towards highperformance antifouling coatings. Biofouling. 27:1139-1150.

Webster DC, Chisholm BJ, Stafslien SJ. In: Hellio C, Yebra DM, Eds. Advances in Marine Antifouling Coatings and Technologies. Cambridge: Woodhead Publishing Ltd, pp. 365392.

Weinman CJ, Finlay JA, Park D, Paik MY, Krishnan S, Sundaram HS, Dimitriou M, Sohn KE, Callow ME, Callow JA, Handlin DL, Willis CL, Kramer EJ, Ober CK. 2009. ABC triblock surface active block copolymer with grafted ethoxylated fluoroalkyl amphiphilic side chains for marine antifouling/fouling-release applications. Langmuir. 25:12266-12274.

Wendt DE, Kowalke GL, Kim J, Singer IL. 2006. Factors that influence coatings performance: the effect of coating thickness on basal plate morphology, growth and critical removal stress of the barnacle Balanus amphitrite. Biofouling. 22:1-9.

Werner C, Maitz MF, Sperling CJ. 2007. Current strategies towards hemocompatible coatings. J Mater Chem. 17:3376-3384.

Vrouwenvelder JS, Hinrichs C, der Meer WGJV, Loosdrecht MCMV, Kruithof JC. 2009. Pressure drop increase by biofilm accumulation in spiral wound RO and NF membrane 
systems: role of substrate concentration, flow velocity, substrate load and flow direction. Biofouling. 25:543-555.

Yasani BR, Martinelli E, Galli G, Glisenti A, Mieszkin S, Callow ME, Callow JA. 2014. A comparison between different fouling-release elastomer coatings containing surface-active polymers. Biofouling. 30:387-399.

Zhu X, Guo S, Janczewski D, Velandia FJP, Teo SL-M, Vancso GJ. 2014. Multilayers of fluorinated amphiphilic polyions for marine fouling prevention. Langmuir. 30:288-296. 


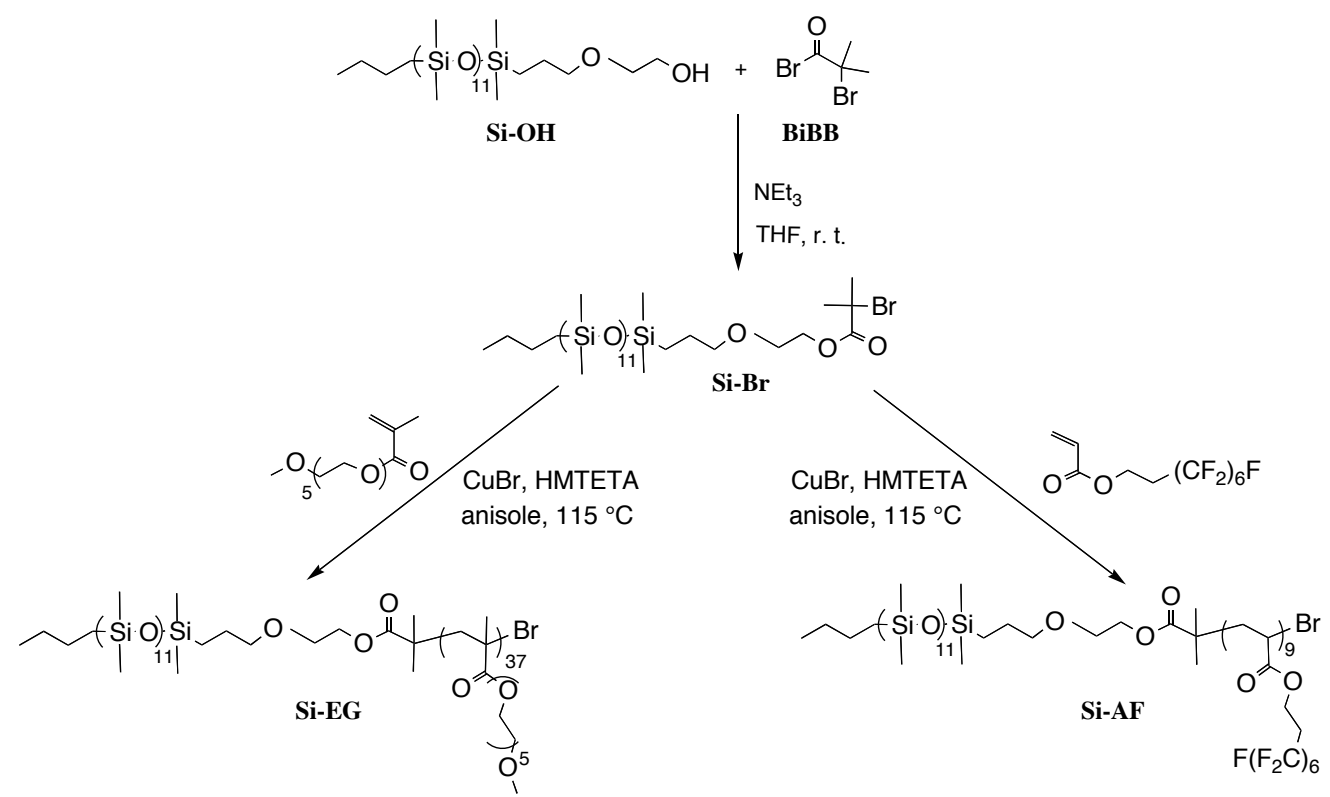

Figure 1. ATRP synthesis of diblock copolymers Si-EG and Si-AF. 

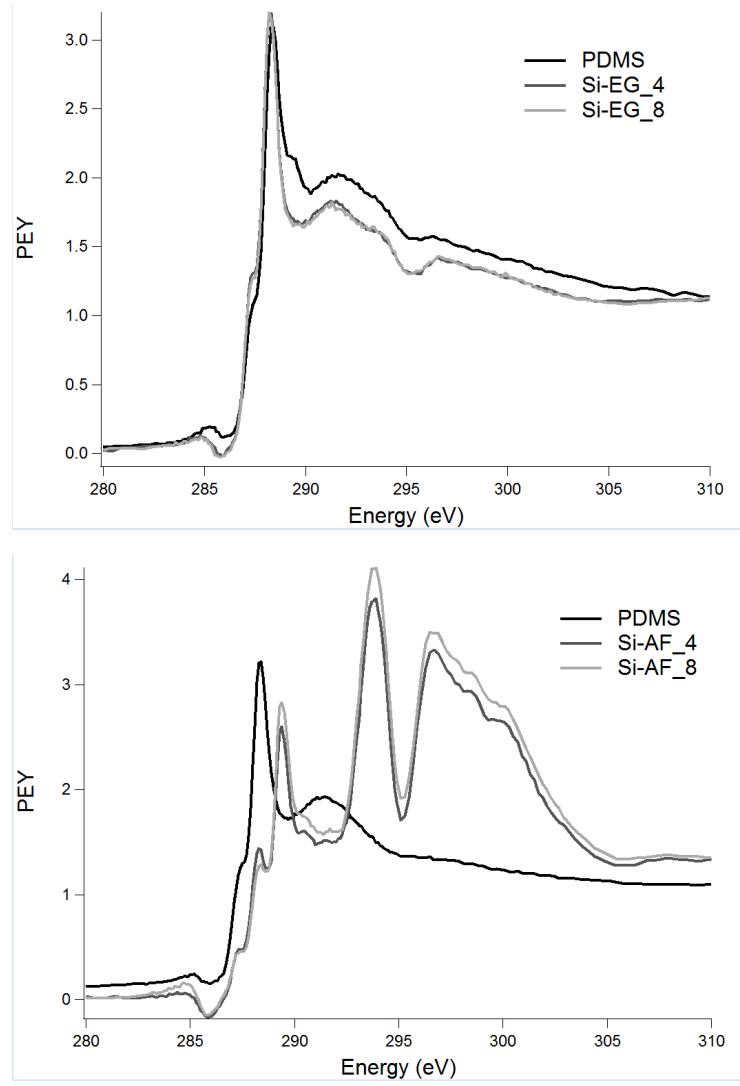

Figure 2. C(1s) NEXAFS spectra of Si-EG_4, Si-EG_8 and PDMS (top) and Si-AF_4, Si-AF_8 and PDMS (bottom) obtained at X-ray incident angle of $\theta=55^{\circ}$. 

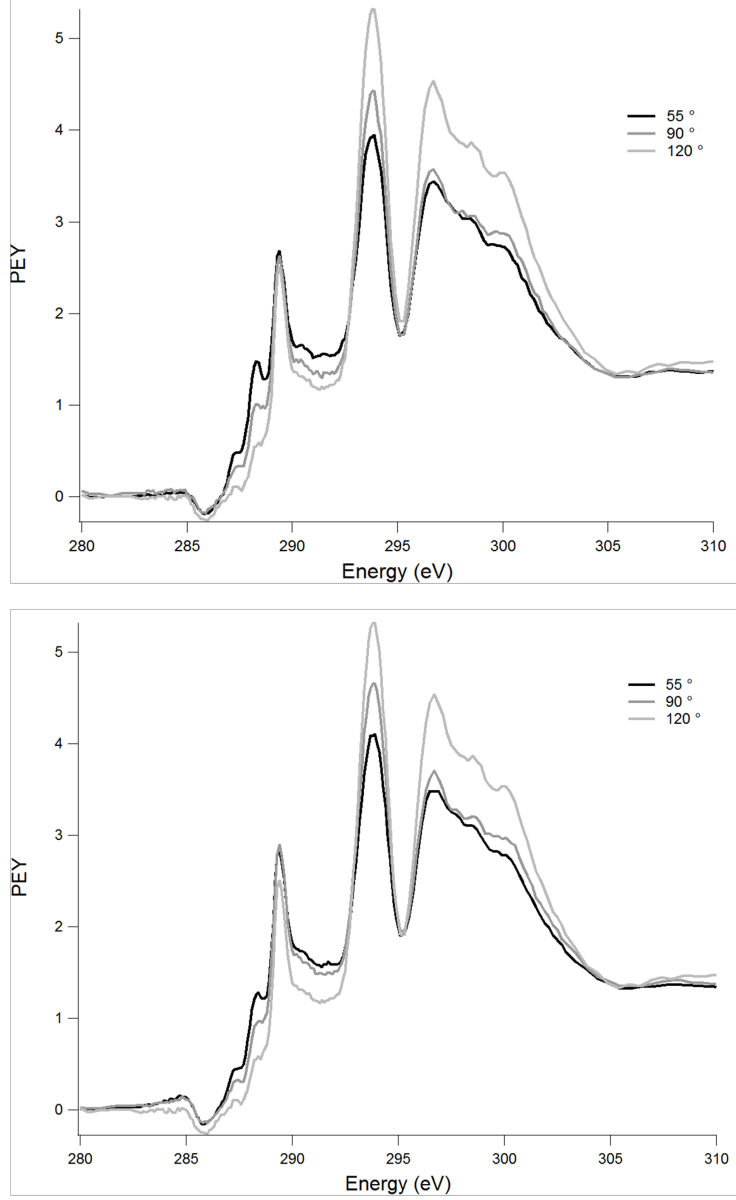

Figure 3. C(1s) NEXAFS spectra for Si-AF_4 (top) and Si-AF_8 (bottom) at varying angles $\theta$. 


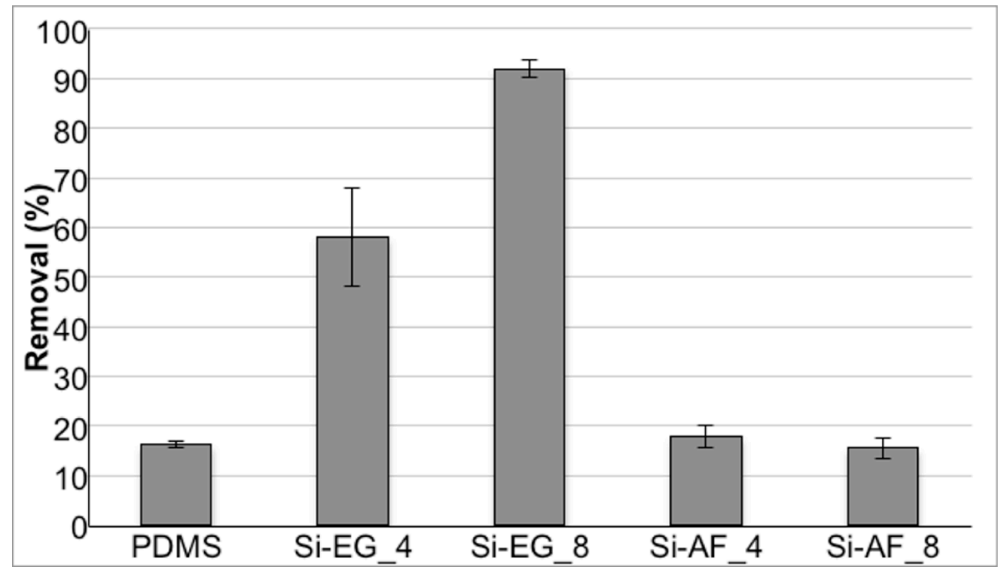

Figure 4. Percentage removal of sporelings of $U$. linza from a PDMS control and PDMS-based films, following exposure to a wall shear stress of $20 \mathrm{~Pa}$. Each bar is the mean of six replicates; each replicate was calculated from 70 readings (before and after exposure to flow). Bars show 2 $\times \mathrm{SE}$ of the mean, calculated from arcsine transformed data. 


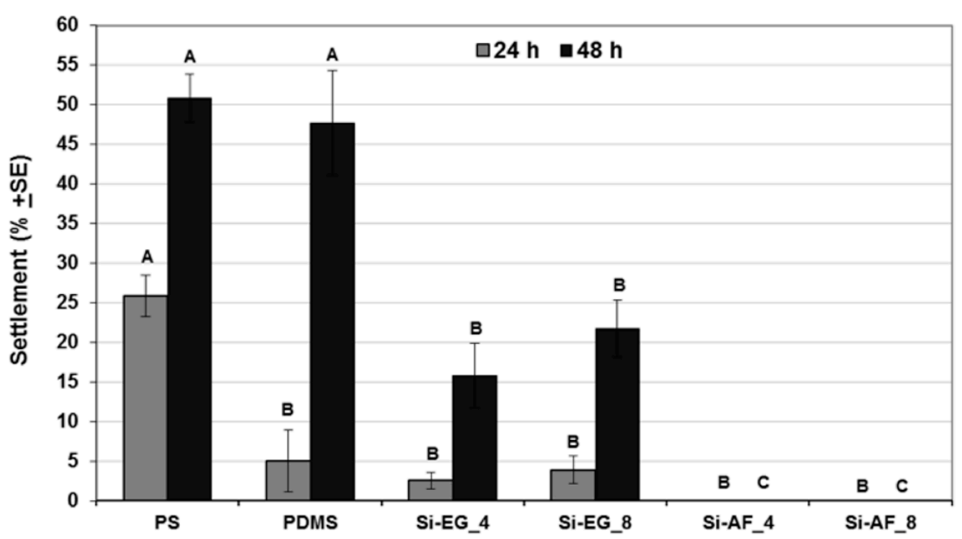

Figure 5. Percentage settlement of 3-day-old B. amphitrite cyprids in polystyrene 24-well plates (PS), and on PDMS control and PDMS-based films. Tukey pairwise comparisons are presented at each time point. Means that do not share a letter are significantly different. 


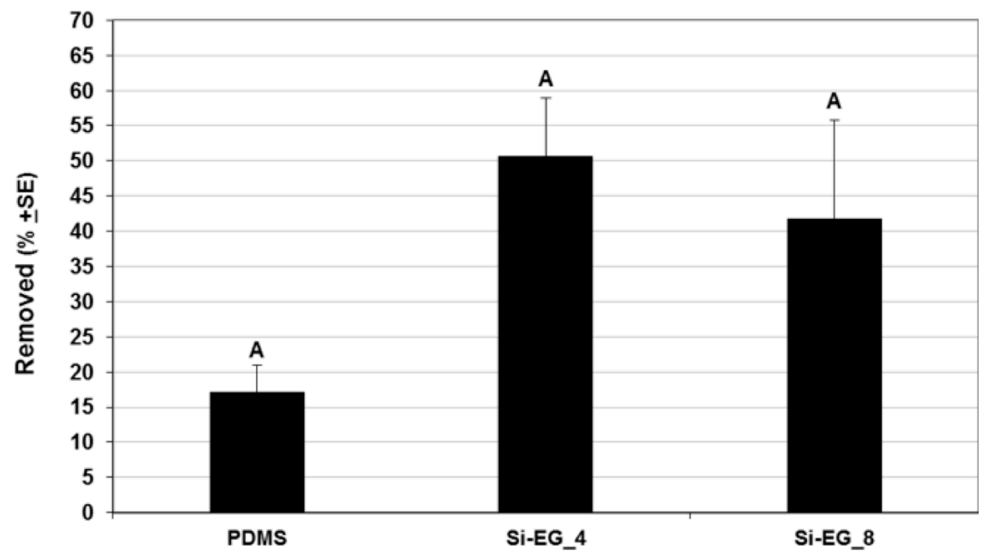

Figure 6. Percentage juveniles removed from a PDMS control, Si-EG_4 and Si-EG_8 following exposure to a wall shear stress of $120 \mathrm{~Pa}$. Si-AF_4 and Si-AF_8 were not tested because no cyprids settled on these surfaces. Tukey pairwise comparisons are presented at each time point. Means that do not share a letter are significantly different. 


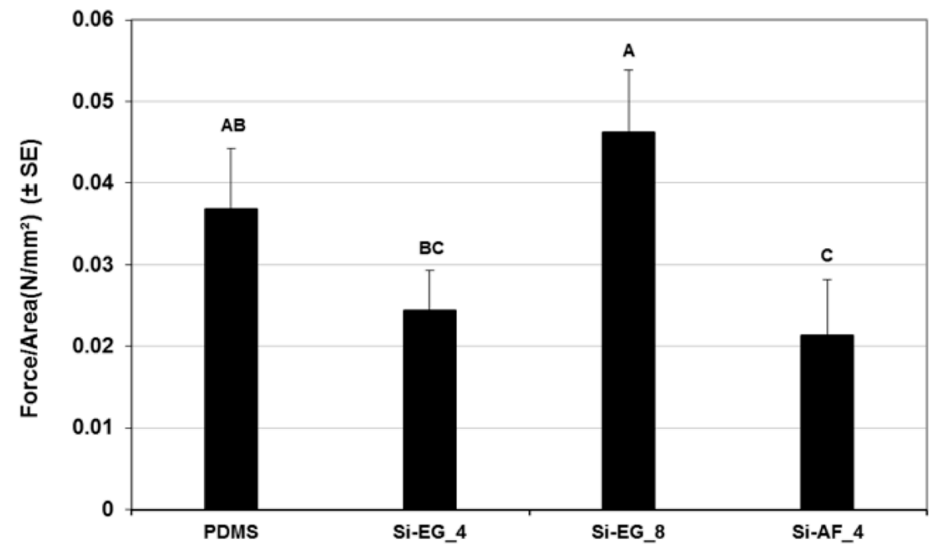

Figure 7. Critical removal stress of adult barnacles from a PDMS control and three PDMS-based films. Tukey pairwise comparisons are presented at each time point. Means that do not share a letter are significantly different. 
Table 1. Advancing and receding contact angles with water and diiodomethane of films.

\begin{tabular}{lcccc}
\hline Film & $\boldsymbol{\theta}_{\mathrm{w}}{ }^{\mathrm{a}}\left(^{\circ}\right)$ & $\boldsymbol{\theta}_{\mathrm{w}}{ }^{\mathrm{r}}\left({ }^{\mathrm{o}}\right)$ & $\boldsymbol{\theta}_{\mathrm{di}}{ }^{\mathrm{a}}\left(^{\mathrm{o}}\right)$ & $\left.\boldsymbol{\theta}_{\mathrm{di}}{ }^{\mathrm{r}}{ }^{\mathrm{o}}\right)$ \\
\hline Si-EG_4 & $101 \pm 1$ & $54 \pm 2$ & $75 \pm 1$ & $43 \pm 1$ \\
Si-EG_8 & $102 \pm 1$ & $62 \pm 1$ & $75 \pm 1$ & $45 \pm 2$ \\
Si-AF_4 & $113 \pm 2$ & $21 \pm 2$ & $93 \pm 2$ & $15 \pm 2$ \\
Si-AF_8 & $114 \pm 1$ & $19 \pm 2$ & $98 \pm 2$ & $14 \pm 2$ \\
PDMS & $106 \pm 2$ & $59 \pm 2$ & $73 \pm 1$ & $39 \pm 2$ \\
\hline
\end{tabular}

